\title{
Coal Carbonization in the Public Service
}

$\mathrm{S}^{\mathrm{o}}$ many articles have apreared during recent years on the subject of coal carbonization and the problem is now so interconnected with political issues that one is apt to lose sight of the basic fact which should determine its technical and economic development.

Mr. E. V. Evans, in a lecture delivered at the Royal Society of Arts, on March 2, made the position abundantly clear. Coal and oil resources which are being exploited to-day took millions of years to accumulate. These resources are being used at an immeasurably greater rate than that at which they were formed and for this reason alone none of them should be wasted, no matter in what countries they are situated. It may be that in future years new types of liquid fuel will be produced from different raw materials to meet the ever-increasing demand for that commodity. At present, however, that consideration does not arise and the process of carbonization should be judged finally on its capability or otherwise of husbanding such natural resources of coal and oil as are known to exist to-day.

Carbonizing and electricity generating industries are each capable of contributing substantially towards conservation of natural resources. As a general rule, in the gas industry to-day the thermal energy of coal is distributed into coke, gas and tar in the proportions of $70: 25: 5$ respectively. Actually 23 heat units of coke are used in the carbonizing process and therefore the thermal efficiency of the process is approximately 77 . On the face of it, it would appear that coal has not been saved but the products obtained are more efficient in use, with the result that in the aggregate a greater thermal efficiency is achieved. Moreover, a certain amount of tar and sulphate of ammonia is obtained and a social benefit conferred by the elimination of atmospheric pollution.

The electrical industry has achieved striking results during recent years. In $1917,3 \cdot 7 \mathrm{lb}$. of coal was required to generate one unit of electricity, whereas to-day approximately $1.48 \mathrm{lb}$. of coal will do the same work. In addition, centralization of power generation has effected great economies. Nevertheless, there is still a tendency among consumers to regard electricity as a very convenient form of fuel and not as a means of transmitting mechanical power. In converting heat energy to mechanical energy approximately two thirds of the original heat energy of the coal is sacrificed. It is definitely uneconomic to use electrical energy for heating purposes. Actual figures can be adduced to show that the capital expended by the electricity companies is two and a half times as great per equivalent ton of raw coal as it is for the gas companies. Each of these industries provides an important public service and the most valuable contribution they can make is to collaborate with each other and be less competitive. There is a great field for expansion of the electrical industry in provision of mechanical power to save human effort, but provision of domestic heat should be the charge of the gas industry.

\section{Special Steels in Marine Engineering}

$\mathrm{I}^{\mathrm{N}}$ response to an invitation to place before the members information concerning the modern special steels with the aim of simplifying their task in availing themselves of the latest metallurgical products, Dr. T. Swinden, director of research to the United Steel Companies, Ltd., delivered before the North East Coast Institution of Engineers and Shipbuilders, on February 25, a paper in which he surveyed the developments of recent years in this sphere. Although his remarks were in many instances more particularly pointed to their applications in hulls, marine boilers, superheaters and engines, his review of the chemical and physical properties of special steels, their amenability to heat treatment, their weldability and their resistance to corrosion and embrittlement were of even wider interest to the engineering profession.

Dealing first with the carbon and low-alloy steels, Dr. Swinden explained the present position as to their special characteristics and then proceeded to enumerate the properties of the more highly alloyed steels which are of increasing importance in engine construction. In addition to comprehensive data of an orthodox character, special attention was given to the subject of fatigue and notch sensitivity, and tables showing results of research on these were included among the many numerical data which the paper contains. From a series of tests on a variety of steels ranging from 20 to 70 tons tensile, it was shown that while the fatigue limit on plain specimens is related approximately to the maximum stress, the notch sensitivity is related roughly to the ductility as measured by elongation. Surface hardening in its various aspects was treated in some detail, the several methods of case carburizing, cyanide hard. ening, the Shorter process, the Tocco surface hardening process and the nitriding process being discussed and their most favourable applications indicated. Dr. Swinden also dealt with the properties of steels made for use at elevated temperatures, and introduced a discussion on creep and creep strength. As a reliable value on which to base design, he commented on the safe working stress indicated by the stress relaxation method of testing for creep.

Finally, after some notes on stainless steel, Dr. Swinden discussed the possibilities of a stainless-faced composite material which consists of mild steel with a facing of about 20 per cent stainless steel. The method of production admits of the combination of plate material with any variety of stainless steel, resulting in a perfect union between the two metals. This material is extensively used in the United States and, as the author stated, one can readily visualize many purposes in shipbuilding and marine engineering where it could be used with advantage and with definite economy as compared with solid stainless steel. 